„Przekłady Literatur Słowiańskich”. T. 9, cz. 3

ISSN 2353-9763 (wersja elektroniczna)

DOI 10.31261/PLS.2019.09.03.08

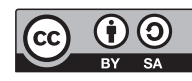

\title{
Bibliografia przekładów literatury czeskiej w Polsce w 2017 roku
}

\section{The Bibliography of Translations of Czech Literature in Poland in 2017}

\author{
Jakob Altmann \\ iD https://orcid.org/0000-0001-7547-6036 \\ UNIVERSITY OF SILESIA IN KATOWICE \\ kuba.alt@interia.pl
}

Data zgłoszenia: 15.09 .2018 r. ｜Ｄata akceptacji: 17.11.2018 r. 


\section{Publikacje książkowe}

1. Aksamitna scena: trzy czeskie sztuki o transformacji.

Tłum. Teresa D u b i cka, Anna Głó w c z yń s ka, Aleksandra Jan e c z e k, Matylda Ko b i ałka, Aleksandra Men sfel, Krzysztof Mor g i e l. Poznań, Instytut Filologii Słowiańskiej Uniwersytetu im. Adama Mickiewicza, Prochowice, Wydawnictwo Pro, 2017, 341 s. [dramat].

Kraus Jan

Nahniličko / Jajko na pótmiękko.

\section{Urban Miloš}

Nože a růže aneb topless party / Noże i róże albo topless party.

\section{Viewegh Michal}

Ri̊že pro Markétu aneb Večírky revolucionářu /

Róże dla Małgorzaty albo przyjęcia rewolucjonistów.

2. Bajaja Antonín: Na krásné modré Dřevnici / Nad piękna, modra Dřevnica. Tłum. Dorota D o b r e w. Wrocław, Książkowe Klimaty, 2017, 556 s. [proza].

3. Boček Evžen: Deník kastelána / Dziennik kasztelana.

Tłum. Mirosław Ś m i g i e ls k i. Wołów, Stara Szkoła, 2017, 220 s. [proza].

4. Bolavá Anna: Do tmy / W ciemność.

Tłum. Agata W r ó b e l. Wrocław, Książkowe Klimaty, 2017, 301 s. [proza].

5. Boučková Tereza: Rok kohouta / Rok koguta.

Tłum. Olga C z e r n i k o w. Wrocław, Afera, 2017, 368 s. [proza].

6. Březinová Ivona: Kluk a pes / Chłopiec i pies.

Tłum. Maria Ma r jań s k a-C z e r n i k. Warszawa,

Prószyński i S-ka - Prószyński Media, 2017, 58 s. [proza].

7. Čapek Karel: Továrna na absolutno / Fabryka absolutu.

Tłum. Paweł H u l k a-L a s k ow s ki. Warszawa,

Fundacja Nowoczesna Polska, 2017, 72 s. [ebook; proza].

8. Denemarková Radka: Př́spěvek k dějinåm radosti / Przyczynek do historii radości.

Tłum. Olga C z e r n i k o w. Wrocław, Amaltea, 2017, 347 s. [proza].

9. Fischl Viktor: Pražské procházky / Praskie przechadzki.

Tłum. Katarzyna B o r u ń-J a g o d z i ń s k a. Kraków, Miniatura, 2017, $64 \mathrm{s.}$ [poezja].

10. Hašek Jaroslav: Osudy dobrého vojáka Švejka za světové války / Przygody dobrego wojaka Szwejka podczas wojny światowej.

Tłum. Paweł H u l k a-L a s k o w s k i. Warszawa, Biblioteka Akustyczna, 2017, 29 godz. 17 min [audiobook; proza]. 
11. Hašek Jaroslav: Osudy dobrého vojáka Švejka za světové války / Przygody dobrego wojaka Szwejka podczas wojny światowej.

Tłum. Antoni K r o h [trzeci przekład]. Wrocław,

Zakład Narodowy im. Ossolińskich, 2017, 843 s. [proza].

12. Hašek Jaroslav: Štastný domov a jiné humoresky / Szczęśliwe gniazdko $i$ inne humoreski.

Tłum. Stefan D ę b s k i. Wydanie 2. Kraków, Wydawnictwo Vis-à-vis Etiuda, 2017, 271 s. [proza].

13. Hořava Matěj: Pálenka. Prózy z Banátu / Palinka. Prozy z Banatu. Tłum. Anna R a d w a n-Ż b i k o w s k a. Wrocław, Książkowe Klimaty, 2017, 188 s. [proza].

14. Kopecká Věra: Slova na vodě / Promyk słowa.

Tłum. Antoni Mat u s zki ew icz. Broumov, Wydawnictwo Věra Kopecká, 2017, 130 s. [poezja].

15. Kopecká Vĕra, Matuszkiewicz Antoni: Ozvĕny v Sovích Horách / Echa z Gór Sowich; Pod Wielką Sowa / Pod Velkou Sovou [wydanie dwujęzyczne].

Tłum. Antoni M a t u s z k i e w i c z, Vĕra K o p e cká. Dzierżoniów, „Edytor” Drukarnia Wydawnictwo, 2017, 92 s. [poezja].

16. Pavel Ota: Pohár od Pánaboha. Pohádka o Raškovi / Puchar od Pana Boga. Tłum. Mirosław Ś m i g i e l s k i. Wołów, Stara Szkoła, 2017, 190 s. [proza].

17. Pech Miroslav: Cobainovi žáci / Uczniowie Cobaina.

Tłum. Mirosław Ś m i g i el s k i. Wołów, Stara Szkoła, 2017, 198 s. [proza].

18. Procházková Iva: Dívky nalehko / Roznegliżowanie.

Tłum. Julia R ó ż e w i c z. Wrocław, Afera, 2017, 416 s. [proza].

19. Reiner Martin: Jeden z milionu / Jeden na milion.

Tłum. Mirosław Ś m i g i el s k i. Wołów, Stara Szkoła, 2017, 158 s. [proza].

20. Svěrák Zdeněk: Jak vyzrát na motýly a další příhody / Nowe ucieszki Cieszka.

Tłum. Dorota D o b r e w. Warszawa, Wydawnictwo Dwie Siostry, 2017, 138 s. [proza].

21. Šabach Petr: Občanský průkaz / Dowód osobisty. Tłum. Julia R ó ż e w i c z. Wrocław, Afera, 2017, 211 s. [proza].

22. Škvorecký Josef: Př́běh inženýra lidských duší / Przypadki inżyniera ludzkich dusz: entertainment ze starymi tematami życia, kobiet, losu, marzeń, klasy robotniczej, tajniaków, miłości i śmierci.

Tłum. Andrzej S. J a g o d z i ń s k i. Wydanie 2 uzupełnione. Warszawa, Dowody na Istnienie, 2017, 733 s. [proza]. 
23. Tranoscius Georgius [Třanovský Jiří]: Cithara sanctorum / Pieśni duchowe: $z$ kancjonatu „Cithara sanctorum”. Tłum. Zbigniew Ma che j. Cieszyn, Oficyna Efemeryczna: Offsetdruk i Media, 2017, 223 s. [poezja].

24. Viewegh Michal: Biomanžel / Ekomaż.

Tłum. Mirosław Ś m i g i e l s k i. Wołów, Stara Szkoła, 2017, 208 s. [proza].

\section{Publikacje w czasopismach}

1. „Ha!art” 2017, nr 4.

\section{Kotleta František}

Spad / Opad.

Tłum. Andrzej S p y r a, s. 35-40 [proza].

2. „Helikopter” 2017, nr 10.

\section{Bondy Egon (Fišer Zbyněk)}

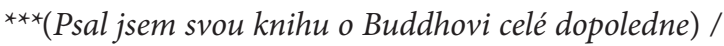

***(Całe popołudnie pisałem swoja księge o Buddzie)

${ }^{* * *}$ (Konec konců koukám) / ***(W końcu dostrzegam $)$

Mír mír mír / Pokój światowy

Spofa Blues / Spofa Blues

Zácpa / Zatwardzenie.

Tłum. Łukasz Tw a rdowski [poezja].

\section{Hložek Ondřej}

Coma Vigile*

Johannsibrunn ${ }^{\star}$

Na razie*

Opava / Opava

Slezská Kalvárie / Kalwaria Śląska

$W$ czasie porywów ${ }^{*}$.

Tłum. Katarzyna C u p ała [poezja].

3. „Helikopter” 2017, nr 11.

\section{Zbořil Jonáš}

***(čtvrtek odpoledne nad břevnovem) /

${ }_{* * *}($ Czwartek po południu nad břevnovem $)$

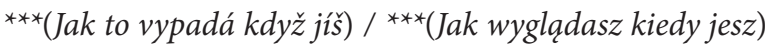

Čekat / Czekać

Ční / Stercza

Hadr / Szmata

Kontinent / Kontynent 
Nebyl tu nikdo kdo by si všiml /

Nie było tu nikogo kto zwróciłby uwage

Rodiče / Rodzice

Sami / Sami.

Tłum. Zofia B ałdyga [poezja].

4. „Inter-. Literatura - Krytyka - Kultura” 2017, nr 2.

\section{Lazarová Zuzana}

Hra na vyloučeného třetího / Gra w wyłączony środek

Kámen ke kameni / Kamień do kamienia

Poslední zhasíná / Gasi ostatni

Zkamenělé slunce / Skamieniałe słońce

Zmizet / Zniknąć.

Tłum. Zofia B ałd y g a, s. 28-35 [poezja].

5. „Kino” 2017, nr 4.

\section{Bednařík Pavel}

Instynkt aktora*.

Tłum. Magdalena Ż u r a w-P e č, Pavel P e č, s. 10-13

[esej].

6. „Kontent” 2017, nr 1.

Škrob Jan

Dublin / Dublin.

Tłum. Magdalena B r o d a c ka.

Já jako vlajkonoš / Ja jako transparentny.

Tłum. Marta Skła d a n ek.

[Z tomu: Pod dlažbou]

Pequawket / Pequawket

Svatá krev / Święta krew.

Tłum. Justyna S u m a, s. 85-94 [poezja].

7. „Kontent” 2017, nr 2.

\section{Doležal Miloš}

Ezechiel v kopřivách I. / Ezechiel w pokrzywach (I)

Ezechiel v kopřivách II. / Ezechiel w pokrzywach (II).

Tłum. Andrzej B a b u ch ow s ki.

Kraków wiosna 2017*

Tankista / Czołgista.

Tłum. Magdalena B r o d a ck a, s. 112-118 [poezja].

8. „Kontent” 2017, nr 4 [wydanie dwujęzyczne].

\section{Orlová Jana}

***(Mi̊j milenec mě provdá) / ***(Mój kochanek mnie wyda)

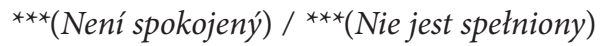




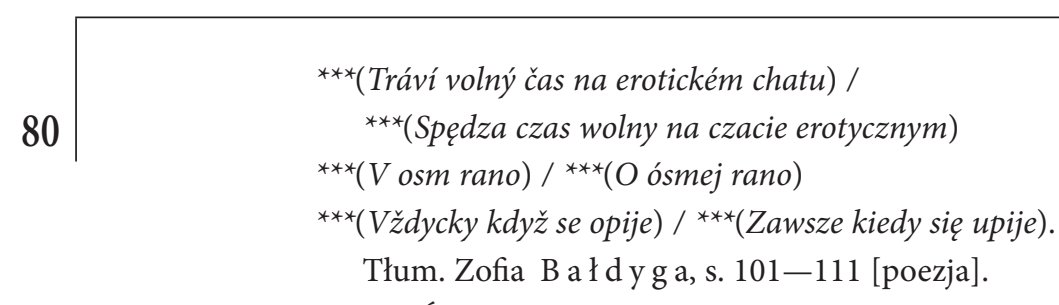

9. „Literatura na Świecie” 2017, nr 7/8.

Škvorecký Josef

Mirákl / Cud [fragment powieści].

Tłum. Andrzej S. J a g o d z i ń s k i, s. 231-302.

Samožerbuch / Autosztambuch [fragment powieści].

Tłum. Jan St a ch ow ski, s. 303-333.

Red Music / Red Music.

Tłum. Elżbieta L e d e r e r, s. 336-353.

Franz Kafka, jazz a jiné marginálie /

Franz Kafka, wypisy antysemickie i inne marginalia.

Tłum. Jacek B r z e zi ń s ki, s. 354-373 [proza].

10. „Odra” 2017, nr 2.

\section{Trojak Bogdan}

Gutský Daidalos / Dedal z Gutów.

Tłum. Michał Ta b a c z y ń ski, s. 55-58 [poezja].

11. „Opowiadania” 2017, nr 5.

Šindelka Marek

Luk / Łuk [opowiadanie z książki: Zůstaňte s nami /

Zostańcie z nami].

Tłum. Anna Wa n i k, s. 199-212 [proza].

12. „Podgląd” 2017, nr 3.

Fischl Viktor

[Ze zbioru Dưm u tři houslí]

Bertramka / Bertramka

Na hrob Františka Halase / Nad grobem Frantiszka Halasa

Socha svatého Jiř́ / Posag świętego Jerzego.

Tłum. Katarzyna B o r u ń-Ja g o d z ińs k a,

s. 190-192 [poezja].

13. „Podgląd” 2017, nr 4.

Opasek Jan Anastáz

Holandská krajina / Holenderski pejzaż.

Katarzyna B or u ń-J a g o d z i ń s k a, s. 203 [poezja].

14. „Pro Libris” 2017, nr 1/4.

\section{Kopecká Vĕra}

Čtvrtý rozmèr / Czwarty wymiar 
Rozchod / Rozstanie

Strom / Cień

Vlny / Fale.

Tłum. Władysław K lę p k a, s. 62-64 [poezja].

15. „Wyspa” 2017, nr 4.

\section{Paterová Natálie}

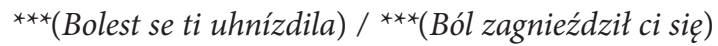

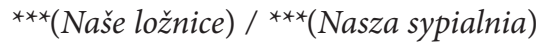

$\left.{ }^{* * *(N i k d o ~ t i ~ n e r ̌ e k n e ~ z ̌ e ~}\right) /{ }^{* * *}$ (Nikt ci nie powie)

${ }^{* * *}($ Potkám ve vlaku $) /{ }^{* * *}(W$ pociagu $)$

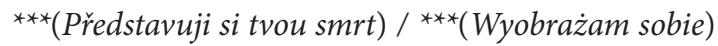

Jarní romance / Romans wiosenny

Jonášovi / Dla Jonáša

Pátek 4/9 / Piątek 4/9

Tato báseň není o nás / Ten wiersz nie jest o nas.

Tłum. Olga Słow ik, s. 50-56 [poezja].

JAKOB ALTMANN | mgr, doktorant w Zakładzie Teorii Literatury i Translacji w Instytucie Filologii Słowiańskiej Uniwersytetu Śląskiego w Katowicach. Absolwent bohemistyki i hispanistyki na Akademii Techniczno-Humanistycznej w Bielsku-Białej. Jako rodowity Niemiec bada niemiecką literaturę drugiej połowy XX wieku ze szczególnym uwzględnieniem literatury niemieckiej noblistki Herty Müller oraz jej polskich i czeskich przekładów, z tego zakresu otrzymał grant w konkursie PRELUDIUM 15. Jego zainteresowania naukowe skupiają się na zagadnieniach językoznawczych, widzianych w kontekście kulturowym. Jest autorem kilku artykułów obejmujących tematy przekładoznawcze i językoznawcze. Publikował m.in. w czasopismach „Przekłady Literatur Słowiańskich” i „Zora” oraz w jednym z tomów serii wydawniczej „Studia o Przekładzie”. Wygłosił referaty na kilku konferencjach krajowych i zagranicznych. 